\title{
Linking Cultural Heritage with Cultural Tourism Development: A Way to Develop Tourism Sustainably
}

\section{Vu Hong Van}

University of Transport and Communications, Hanoi, Vietnam

\begin{abstract}
This study presents the main ideas of sustainable cultural tourism development, a form of tourism associated with work discover and explore the culture of each region. It implies taking into account economic, environmental and socio-cultural aspects by tourism planning and management. The paper presents the historical background of the idea of sustainability, the factors that affect the sustainability of culture in tourism development. The author emphasizes the negative effects of tourism on cultural preservation that can be prevented by applying the principles of sustainable development; at the same time, propose solutions to balance economic development and cultural preservation.
\end{abstract}

Keywords: Sustainable, cultural heritage, cultural tourism development, Vietnam

\section{Introduction}

Currently, there are many types of tourism (Sultan \& Banu, 2018). According to the criteria of tourism resources and tourism needs, there are natural eco-tourism types and cultural tourism types. The natural eco-tourism meets the need to explore and immerse in the nature of visitors, organized based on the attraction of natural tourism resources. Cultural tourism is organized based on the exploitation of the cultural values of the destination, meeting the tourist needs to learn about the country, people and culture of the tourist destination. In those forms of tourism, cultural tourism plays an important role in sustainable tourism development.

Sustainable tourism is the concept of visiting somewhere as a tourist and trying to make a positive impact on the environment, society, and economy (Peeters \& Dubois, 2010). Tourism can involve primary transportation to the general location, local transportation, accommodations, entertainment, recreation, nourishment and shopping. It can be related to travel for leisure, business and what is called VFR (visiting friends and relatives) (Peeters \& Dubois, 2010). There is now a broad consensus that tourism development should be sustainable; however, the question of how to achieve this remains an object of debate.

Sustainability is a popular trend in nowadays life, concerning development and operation, also in the tourism sector. However, there is confusion about the different meanings of sustainability and whether it can be achieved in tourism (Dwyer \& Edwards, 2010). Therefore a problem arises: does sustainable development apply to cultural tourism? The purpose of this paper is to reveal the necessity of sustainable development in cultural tourism, in the conditions of both economic development and environmental protection, at the same time protecting cultural heritage. The object of this article is to present sustainable cultural tourism: the concept of sustainable tourism development and protect cultural heritage. Moreover, the author presents its own critical view on sustainable tourism development in Vietnam- the current situation and the need for change. The tasks arising from the purpose are as following: to present economic aspect, environmental aspect, and socio-cultural aspect influencing sustainable cultural tourism development. The monographic and descriptive method was applied in the paper. It is worth emphasizing that there is a large number of American and English literature on the topic. Sustainable tourism is a term often explained, described, and used in Western tourism handbooks, sometimes even as a separate publication. However, there is not much literature in 
Vietnam publications. It may be due to the low level of development of the tourism sector in Vietnam either due to the lack of interest from tourism management authorities, or the lack of comprehensive links between tourism management authorities and cultural management authorities in Vietnam. The other reason may be little interest in the issue of sustainability among touristic facility management and tourism activities at cultural heritage sites. Most of Vietnam the literature base on foreign bibliography and international documents introducing sustainability principles.

\section{Literature Review}

\subsection{Concept of Sustainable Development}

To explore the principles and objectives of sustainable cultural tourism development first it is necessary to define the term sustainable development. Despite the widespread acceptance of sustainable development, there remains a lack of consensus over the actual meaning of this term. It means different things to different people and can be applied to any context, including tourism. The concept of sustainability first appeared in the public sense in the report by the World Commission on Environment and Development (WCED) in 1987. The outline of sustainable development is that economic growth and environmental conservation are not only friendly but they are partners and one cannot survive without than others. The Brundtland Commission Report sustainable development as "development that meets the needs of the present without compromising the ability of future generations to meet their own needs" (WCED, 1987).

WCED (1987) written: Sustainable development is one that meets the needs of the present generation without comprising the ability for future generations to meet their own needs". The modern concept of sustainable development from the WCED (1987) is also rooted in earlier ideas about sustainable forest management and twentieth-century environmental concerns. However, when the world economy developed, it has shifted its focus more towards economic development, social development, and environmental protection for future generations. It has been suggested that the term "sustainability" should be viewed as humanity's target goal of human-ecosystem equilibrium, while "sustainable development" refers to the holistic approach and temporal processes that lead us to the endpoint of sustainability (Shaker, 2015). Modern economies are endeavoring to reconcile ambitious economic development and obligations of preserving natural resources and ecosystems, as the two are usually seen as of conflicting nature. Instead of holding climate change commitments and other sustainability measures as a remedy to economic development, turning and leveraging them into market opportunities will do greater good.

The concept of sustainable development variously described as eco-development, self-sustaining development, or suspensory development. Sustainable development is based on three pillars: economic development, environmental protection, and social development. Recently the term "social development" is being replaced as the "socio-cultural development". This concept assumes a properly and consciously shaped relationship between the pillars, which are intended to ensure intra and economic, environmental, and social balance inter-generational (Meyer \& Milewski, 2009).

\subsection{Concept of Sustainable Tourism Development}

Sustainable tourism development and sustainable development have a very close relationship. In fact, sustainable development and sustainable tourism development are both related to the environment. In tourism, the environment has a very broad connotation. It is the natural, economic, cultural, political, and social environment; is a very important factor to create diversified and unique tourism products. 
Obviously, without environmental protection, the development would decline; but if there is no development, the environmental protection will fail. Therefore, we need to develop tourism but must not harm resources, not negatively affect the environment. In other words, sustainable tourism must be the development trend of the tourism industry.

Tourism has become a major economic activity within developed and developing countries, often contributing more foreign currency than traditional primary commodity exports. The growth in the tourism sector and its maturity made people concern that the resources of host countries might be exhausted. Attention has been paid to the relationship between tourism and the environment and to the problems associated with tourism expansion (Philip \& Gianna, 1985).

In addition to environmentally friendly development, the concept of sustainability also includes a tourism approach that recognizes the role of the local community, the treatment of labor, and the desire to maximize the economic benefits of tourism for the local community. In other words, sustainable tourism is not only about environmental protection, but also about the long-term economic viability and social equity. Sustainable tourism cannot be separated from sustainable development.

Sustainable tourism development is defined as all forms of activities, management, and development of tourism that preserve natural, economic, and social integrity and guarantee the maintenance of natural and cultural resources. Sustainable tourism development guidelines and management practices are applicable to all forms of tourism in all types of destinations, including mass tourism and the various niche tourism segments.

In many research found that "sustainability is praised a positive approach intended to reduce the tensions and friction created by the complex interactions between the tourism industry, tourists, environment and the host communities to maintain the long term capacity and quality of both natural and human resources" (Bramwell \& Lane, 1993).

Currently, there is still no consensus in the world on the concept of sustainable tourism development. Sustainable tourism is defined in a number of ways.

Machado (2003) has defined sustainable tourism as: "Types of tourism that meet the current needs of tourists, the tourism industry, and the local community, but do not affect their ability to respond needs of generations to come. Tourism is economically viable but does not destroy resources on which the future of tourism depends, especially the natural environment and social structures of local communities". This definition focuses on the sustainability of the tourism forms (tourism products), but does not generally mention the sustainability of the entire tourism industry.

According to the World Travel and Tourism Council (WTTC), 1996, "Sustainable tourism is about meeting the current needs of tourists and tourism areas while ensuring the ability to meet the needs of future generations of tourism". This is a brief definition based on UNCED's definition of sustainable development. However, this definition is too general, only referring to the satisfaction of the needs of current and future visitors, not to mention the needs of local communities, ecological and diverse environment biological, etc.

According to Hens L. (1998): "Sustainable tourism requires managing all types of resources in some way so that we can meet the economic, social and aesthetic needs while maintaining cultural identity, basic ecological processes, biodiversity, and life-guarantee systems ". This definition only focuses on the management of tourism resources for sustainable tourism development. 
At the 1992 United Nations Conference on Environment and Development in Rio de Janeiro, the World Tourism Organization (UNWTO) defined: "Sustainable tourism is the development of tourism activities to respond to the current needs of tourists and indigenous peoples while being concerned with the conservation and improvement of resources for future tourism development. Sustainable tourism aims to satisfy the economic, social, and aesthetic needs of human beings while maintaining cultural integrity, biodiversity, the development of ecosystems, and support systems for human life" (Luong, 2002). This definition is a bit long but contains a full range of contents, activities, and factors related to sustainable tourism. This definition has also focused on local communities, protecting the ecological environment, preserving cultural identity. In this thesis, the concept of sustainable tourism development is understood according to the connotation of the definition of the World Tourism Organization (UNWTO), in 1992. The goals of sustainable tourism according to Inskeep (1995) detail are:

- To develop and increase the contribution of tourism to the economy and the environment;

- Improving social equity in development;

- Improve the quality of life of indigenous communities;

- Highly satisfying the needs of visitors;

- Maintain quality of the environment.

Thus, with the above views, it can be considered that sustainable tourism development is a branch of sustainable development in general, determined in 1987. Development by the Conference of the World Commission on Development and Environment. Sustainable tourism development is the activity of developing tourism in a specific area so that the content, form, and scale are appropriate and sustainable over time, do not degrade the environment, and do not affect the ability to support other development activities. On the contrary, the sustainability of tourism development activities is built on the foundation of success in the development of other industries, the sustainable development of the entire society.

\subsection{Views on Cultural Tourism}

Cultural tourism is a form of tourism based on the national cultural identity with the participation of the community to preserve and promote traditional cultural values. In addition to types of tourism such as ecotourism, medical examination and treatment, adventure tourism, educational tourism, etc. recently, cultural tourism is considered a typical product of developing countries, attracting many international tourists.

Cultural tourism mainly relies on cultural products, traditional ethnic festivals, including religious customs, beliefs, etc. to create attraction to local tourists and from all over the world.

For tourists interested in researching and exploring local culture and customs, cultural tourism is an opportunity to satisfy their needs. Most of the cultural tourism activities are closely related to the locality - a place where many cultural festivals are kept and also a place where poverty exists.

Tourists in developed countries often choose festivals of countries to organize foreign tours. Therefore, attracting tourists to cultural tourism means creating a new flow and improving the lives of local people.

In underdeveloped or developing countries, development platforms largely do not rely on large investments to create expensive tourist destinations, but rather on natural tourism resources and diversity of identity nation. These resources do not create great value for the tourism industry but 
contribute significantly to the development of the social community. Countries that develop strong cultural tourism are Thailand, Indonesia, Malaysia, China, and some countries in South America, etc.

Cultural tourism is a trend in many countries. This type of tourism is very suitable for the Vietnamese context, very good for the national poverty alleviation, so it must be considered as a development direction of Vietnam's tourism industry.

In Vietnam, many cultural tourism activities are organized based on regional characteristics. The program of Land Phuong Nam Festival (Folklore Festival of the Southern Delta region). Dien Bien Tourism (Northwest cultural festival combined with political events: 50 years of victory in Dien Bien Phu), Central Heritage Road (folk festival combined with visiting cultural heritage by UNESCO recognition), etc. as activities of cultural tourism, attracting many domestic and foreign tourists. Among them, the Hue Festival is considered to be the most unique cultural tourism activity in Vietnam. In addition, in Vietnam, there are currently 22 tangible heritages recognized by UNESCO as world tangible heritages such as Complex of Hue ancient capital, Hoi An ancient town, My Son Sanctuary, Thang Long Citadel, the citadel of the Ho Dynasty, etc all have become important cultural tourist destinations for domestic and foreign tourists.

\subsection{Cultural Heritage}

The term 'cultural heritage' has changed content considerably in recent decades, partially owing to the instruments developed by UNESCO. Cultural heritage does not end at monuments and collections of objects. It also includes traditions or living expressions inherited from our ancestors and passed on to our descendants, such as oral traditions, performing arts, social practices, rituals, festive events, knowledge, and practices concerning nature and the universe or the knowledge and skills to produce traditional crafts (UNESCO, 2004). Cultural Heritage is an expression of the ways of living developed by a community and passed on from generation to generation, including customs, practices, places, objects, artistic expressions, and values. Cultural Heritage is often expressed as either Intangible or Tangible Cultural Heritage (ICOMOS, 2002).

Chapter VII - Implementation Provisions (Articles 73 to 74) (2001), the Law on Cultural Heritage of Vietnam has provisions on cultural heritage. Cultural heritage in this Law is understood to include both intangible cultural heritages and tangible cultural heritage. They are spiritual and material products with historical, cultural, and scientific values, handed down from generation to generation. Intangible cultural heritage is a provincial product of historical, cultural, and scientific value, preserved by memory, written, handed down by word of mouth, craft, performance, and forms. Other archival and transmission, including voice, writing, literary works, art, science, oral language, folk performance, lifestyle, lifestyle, festival, craft know-how traditional work, knowledge of medicine, traditional medicine, culinary culture, traditional costumes, and other folk knowledge. Physical cultural heritage is a material product of historical, cultural, or scientific value, including historical-cultural relics, scenic spots, relics, antiques, national treasures, etc.

Vietnam's cultural heritage is a valuable asset of the community of Vietnamese ethnic groups and is a part of human cultural heritage, playing a great role in the cause of building and defending the country of the people. protect and promote the value of cultural heritages, meet the increasing cultural needs of the people, contribute to building and developing an advanced Vietnamese culture, imbued with national identity and contribute to the world cultural heritage treasure house and to strengthen the 
effectiveness of state management, to enhance the people's responsibility to participate in the protection and promotion of cultural heritage values.

As part of human activity, Cultural Heritage produces tangible representations of the value systems, beliefs, traditions, and lifestyles. As an essential part of the culture as a whole, the cultural heritage contains these visible and tangible traces from antiquity and today.

\section{Relationship between Culture and Tourism}

For many years in our country, there has been a very convincing lesson and experience that culture in tourism in our country is both as an orientation goal and as a view that affirms that culture is the content, the true nature of Vietnam's tourism, creating the most unique, unique and attractive of Vietnam's tourism products, contributing to building the national image in the eyes of international friends.

Tourism is a human social practice, it is formed by the organic combination of the three elements of the traveler, the tourism resource, and the travel agency. The tourist is the tourist subject, the tourism resource is the tourist subject and the tourism industry is the broker providing services to tourists. In terms of socio-cultural, tourism is a high-level cultural activity of people. Because culture is the purpose that tourism aims for, is the endogenous cause of tourism demand. No matter what the purpose of the traveling person (visit, study, study, sightseeing, relax, etc.) or by any mode (road, rail, sea, air, etc.), the end purpose the same is to satisfy their own needs, to feel and enjoy the material and spiritual values created by people in a country outside of their regular residence. In other words, tourism is human behavior with the natural and social environment in order to benefit them and is a beneficial activity to promote human intellectual development.

It is a general statement and a specific expression of the close relationship between culture and tourism is expressed through the following aspects:

Culture is a unique resource of tourism (the source of raw materials to form tourism activities). When we say culture is the raw material to form tourism activities, we mean the attraction/beneficiary of the tourist. Cultural materials have two basic types: Physical culture is human creations that exist, exist in a space that can be perceived by sight, touch, such as historical and cultural relic's culture, handicrafts, tools in seed production, production, ethnic dishes, etc. An intangible culture such as festivals, art forms, behavior, communication ... According to the conception of In the tourism industry, cultural elements are classified into human resources (as opposed to natural resources such as seas, rivers, lakes, mountains, caves, etc.), namely: Historical - cultural relics; souvenir goods of national characteristics; cuisine; festival; entertaining games; customs, practices, behavior, communication; religious beliefs; literature - art.

Therefore, culture is the condition and environment for tourism to arise and develop. Along with natural resources, cultural resources are one of the typical conditions for tourism development of a country, region, and locality. The value of cultural heritage: historic sites, architectural works, art forms, customs, festivals, traditional professions, etc. together with economic, political, and communal achievements associations, cultural and art establishments, museums, etc. are objects for tourists to explore, enjoy, for tourism to exploit and use. The exploitation and profit from natural resources and the construction of tourist sites reflect the intelligence and creativity of mankind. It is these resources that not only create the environment and conditions for tourism to arise and develop, but also determine the scale, type, quality and efficiency of tourism activities of a country, a region, a locality. 
The relationship between tourism and culture is also manifested through behavior, ethics in service, or in tourism business transactions. The essence of the relationship between culture and business in general and tourism in particular (or the role of culture in economic development) has been affirmed. In other words, business behavior to be successful must be done culturally. Can be called collectively as business art or business culture.

In another aspect, this close relationship is shown: if tourism development needs to have a good tourism environment (including the natural and human environment - these two factors inseparable). The natural environment such as no dirt, clean water, no writing on rocks, etc. the humanistic environment is a relic that is preserved, residents, employees working in the tourist area must have culture and quality complete culture, policy, legal system, etc.

Knowledge, social information, behavior, psychological understanding of tourists, etc. are effective drivers to promote tourism development.

In contrast to culture, tourism also plays a very important role in this relationship. Tourism becomes a means to convey and show the cultural values of a locality and people for all domestic and international tourists to explore, admire, learn, and enjoy.

Thanks to tourism, cultural exchanges between communities and countries are strengthened and expanded.

Tourism is also a means to awaken and revive the national cultural values that are submerged or fading overtime before historical events. These can be ancient architectural works, a living custom, a folk tune, a national dish, etc. showing the artistic, cultural, and technical level of the past times. Thanks to tourism, these cultural assets are restored, exploited, and embellished, serving the need to validate the values of that heritage.

\section{Cultural Heritage with Tourism Development}

\subsection{Cultural Heritage Motivates Tourism Development}

Cultural heritage is a tourist resource with a strong attraction and a driving force that attracts more and more domestic and international tourists to Vietnam. Currently, the tourism industry considers this as an important foundation and pillar for the development of the tourism economy in addition to the elements of infrastructure, specialized technical facilities, and human resources. Cultural heritage is also an active support tool in image positioning and branding for Vietnam tourism.

We have the right to be proud of the country's long history of 54 ethnic groups, which has left today a huge treasure of cultural heritage, extremely rich, diverse, and unique. Up to now, there are 24 tangible, intangible and natural cultural heritages honored by UNESCO as world heritage; including 8 natural and cultural heritages (Ha Long Bay, Thang Long Imperial Citadel, Trang An scenic complex, Nha Ho Citadel, Phong Nha Ke Bang, Hue ancient capital, Hoi An ancient town, My Son Sanctuary); 12 intangible cultural heritages (Hue Imperial Court Music, Central Highlands Gong Culture Space, Quan Ho Folk Songs, Giong Festival, Ca Tru, Xoan singing, Hung Vuong worshiping beliefs, Mother worship beliefs, Vietnamese folk songs, Nghe Tinh folk songs, Tug of war, Don ca Tai Tu of Southern; Singing Song Bai Choi of the Central Coast); and 4 documentary heritages (stele of Dr. Van Mieu Quoc Tu Giam, Woodblocks of the Nguyen Dynasty, Chau Ban of the Nguyen Dynasty, Truc Lam woodblocks of Truc Lam Buddhist sect at Vinh Nghiem pagoda, Bac Giang province). Along with that are tens of thousands of historical, cultural, and scenic heritage. Only the physical cultural heritages are 
estimated to have more than 3,000 national heritages and about 7,500 provincial-level heritages and many monuments are still being counted; a system of festivals, traditional craft villages; culinary culture of regions and ethnic groups; folk cultural heritages, etc.

On the basis of promoting the unique cultural heritage values of each type of heritage, in recent years, heritage tourism has grown strongly, the number of domestic and international visitors has been constantly participating increase, especially the heritage after being recognized by the State and honored by UNESCO. The attractiveness of the heritage has motivated tourism development, bringing many benefits in terms of income, employment, and local socio-economic development. Specifically, the Complex of Hue Ancient Monuments, in 2017 welcomed 3 million tourists, of which 1.8 million were international tourists, earned 320 billion VND from entrance tickets; Hoi An Ancient Town welcomed 1.96 million visitors, earning 219 billion VND from entrance tickets. Famous heritages such as Ha Long Bay, Phong Nha-Ke Bang Cave, Trang An scenic complex, Yen Tu Mountain, Ba Den Mountain, etc. in recent years are constantly being invented and developed. Thereby, heritage tourism has made a great contribution to the outstanding development of the tourism industry in recent years. Specifically, from 2010 to now, the number of international visitors to Vietnam has increased by more than 2.5 times, from 5 million in 2010 to 12.9 million in 2017, an average increase of $14.5 \%$ per year (especially differences in 2017 increased by $29.1 \%$ compared to 2016). Domestic tourists increased by 2.6 times, from 28 million in 2010 to 73.2 million in 2017, an average increase of $14.6 \%$. Total tourism revenue increased by more than 5 times, from 96,000 billion in 2010 to 510,000 billion in 2017, an average increase of $26.9 \%$, contributing over 7\% of GDP and the spillover effect is over $13.9 \%$ of GDP; create over 1.2 million direct jobs and 3.6 million indirect jobs (Vietnam National Administration of Tourism, 2019). Many heritage tourism products have become typical brands for Vietnamese tourism. In particular, cultural heritage is also an important factor that makes a difference to the destination system and tourism products of Vietnam, connecting and diversifying trans-regional and international tourist routes.

\subsection{Tourism Promotes Cultural Heritage Values}

In the world, cultural tourism has long been and will forever be a basic school or product line of tourism. Especially for countries and territories with a cultural depth measured by a dense heritage system like our country, heritage tourism becomes one of the outstanding strengths. Today, heritage tourism aims to attract visitors to find source values, learn, interact, and experience to absorb cultural heritage values imbued with the identities of ethnic groups and ethnic groups. In our country, the policy of tourism development on the basis of preserving and promoting the fine traditional cultural heritages of the nation has been expressed in the Politburo's Resolution 08-NQ/TW on development tourism development becomes a spearhead economic sector. Cultural tourism is therefore a key product line of Vietnamese tourism, from visiting cultural-historical sites, systems of museums, cultural works, art activities, exploring, interact, experience local culture, festivals, lifestyle, enjoy regional cuisine and products, etc.

It can be said that tourism has promoted the protection of the country's cultural treasures. It is the needs of visitors to visit, learn, and experience that motivates the government and people to appreciate, be proud, take care of, preserve, restore, and clarify and promote the values precious capital of cultural heritage. Heritage-based tourism activities in many places such as Hue, Hoi An, Ha Long, etc. have become the basis and main driving force for livelihoods, the main industries of the people as well as the main economic sectors of the locality. Phuong. Heritage tourism creates both income and 
employment, both creating motivation and creating resources to preserve and promote heritage values; at the same time, actively support to improve the quality of life, increase understanding, respect for diversity and cross cultures, as a basis for forming a suitable code of conduct between people and tourists and heritage. The benefits of heritage tourism are not small and shared with businesses and people. Some of the revenue from heritage tourism is returned to be reinvested in heritage conservation, embellishment, honor, restoration, and management. In that sense, heritage tourism makes a great contribution to the conservation and sustainable promotion of cultural heritage.

However, in the current strong growing tourism trend, especially mass tourism has had and is having negative impacts on cultural heritage. Due to the sensitive and vulnerable nature of the heritage, the mass tourism movement lacks control in many places, especially the famous heritages in our country that are spreading many impacts aspects such as overexploitation of commercialization, overloading of guests, abuse of heritage, improper restoration, heritage renewal, etc. make the legacy quickly degrade, distort, and fade its value, etc. The consequences of uncontrolled and unsustainable heritage tourism development are threatening the integrity of the heritage. Over the past time, in some famous heritage, there have been development investment activities, including serious damage to the heritage that the next phase will pay very expensive prices for the restoration of diurnal value property has been compromised. On the other hand, tourism is too commercialized, cultural value boring; the risk of fading identity, disrupting local traditions and lifestyles; increasing community divisions, conflicts of interest, conflicts of right to access resources, including cultural heritage resources, etc. are raising alarm bells for stakeholders in sustainable management firmly cultural heritage resources in tourism development.

\section{The Fundamental Goals of Sustainable Tourism Development}

In order to develop cultural tourism and build sustainable development principles, it is necessary to first define the basic goals. That is:

Economic efficiency: Ensuring economic efficiency and competitiveness so that businesses and tourist destinations can continue to prosper and achieve long-term profits.

Local development: Maximize the contribution of visitors to the prosperity of the local economy in tourist sites, tourist areas, include spending of tourists are kept locally.

Creating jobs and raising income levels: Increasing the quantity and quality of local jobs created by the tourism industry and supported by the tourism industry, without gender discrimination and other aspects.

Social equity: There is a need for a fair and generous redistribution of the economic and social benefits of tourism to all in the community that deserves it.

Meet the satisfaction of tourists: Provide safe, quality services to satisfy the needs of tourists.

Enhancing the functional role of the tourism organizer: Attracting and empowering local communities to plan and make tourism development and management decisions, in consultation with related parties.

Social security: Maintain and enhance the quality of life of local people, including social organizational structure and access to resources, life support systems, avoid degradation and environmental as well as social excessive falls in all its forms. 
Preservation of cultural values: Respect and increase the value of historical heritages, national cultural identities, traditions, and special identities of local communities at tourist sites.

Protect nature: Maintain and improve the quality of landscapes, both in rural and urban areas, to avoid environmental degradation.

Efficient use of resources: Minimize the use of rare and non-renewable resources in the development and deployment of tourism facilities, facilities, and services.

Protecting the environment: Minimize pollution of the air, water, soil, and waste from tourists and travel agencies.

\section{The Principles of Sustainable Tourism Development}

Tourism is an integrated economic industry, interdisciplinary, inter-regional, and highly socialized, wanting to develop sustainably requires a joint effort of the whole society. The goal of sustainable development is to bring harmony between socio-economic and environment but does not affect the future. In order to accomplish the above objectives, it is necessary to identify the principles of sustainable tourism development, taking as a guideline for the next activities, helping tourism to develop sustainably in the future.

Exploiting and using resources appropriately: Resources are the overall geographical location, natural resources, the national property system, human resources, policy lines, capital, and market, etc. both Foreign and foreign countries can be exploited for tourism development. The sustainable use and conservation of natural, socio-cultural natural resources are essential to ensure the long-term development, exploitation for tourism activities based on current needs calculation.

Minimize excessive consumption of natural resources: Consumption of natural resources at a sufficient level helps to restore natural resources, on the other hand, reduce waste to the environment. Natural resources should be planned and managed to avoid massive exploitation or hot development.

Maintaining conservation of the natural, social and human diversity: It is necessary to respect the diversity of nature, society, and environment of the destination, ensure the pace, scale, and type of tourism development, to protect the diversity of the local culture. Considering the size and capacity of each region, closely monitoring tourism activities for flora and fauna, integrating tourism activities into activities of the community, preventing the substitution of industries. The traditional profession is as long as in modern professions. Develop tourism in accordance with local culture, social welfare, development needs, ensure the scale and progress of different types of tourism in order to increase mutual understanding between tourists and people resident in, etc.

Tourism development must be placed in the socio-economic master plan: The long-term existence of the tourism industry must be within the strategic framework of the country, region, and locality in terms of socio-economic issues. To ensure development, the tourism industry needs to take into account the immediate needs of both residents and visitors, in the planning, it is necessary to unify socioeconomic, environmental aspects, respect the national strategy country, region, territory, and locality. Development of the tourism industry must be consistent with the locality, in accordance with the planning assigned by the locality, that development must be sustainable and long-term.

Tourism development must support the local economy: With its interdisciplinary characteristics, sustainable development is not only itself but also involves many other fields. In the tourism sector, 
support for other industries not only for businesses directly involved in tourism but also for many businesses indirectly participating in this activity, which in turn leads to business support local health.

Attracting local communities to participate in sustainable tourism development: Local community involvement is a guaranteed factor for sustainable tourism development. When local communities are involved in tourism development, tourism will be created many favorable conditions, because the participation of local communities will attach the rights and responsibilities of each resident to the overall development of travel.

Get opinions from the people and stakeholders: Consult stakeholders and residential communities, domestic and foreign organizations, non-governmental organizations, and government with ideas for the project. , is an important principle in sustainable tourism development. Sharing the interests of the parties is aimed at harmonizing the interests in the implementation process.

Focusing on the training of human resources: With sustainable tourism development, training, and developing human resources is an extremely necessary task. There is a huge shortage of labor force in the tourism sector and professionally trained workers that have not met the general needs of the industry. A skilled workforce that not only brings economic benefits to the industry but also improves the quality of tourism products.

Attaching importance to scientific research in the tourism industry: In order for tourism to become a professional, modern, and sustainable economic sector, scientific research plays an important role in building strategies, planning, planning, training, and implementing tourism development activities. The scientific and technological achievements in tourism in the past years have become important scientific foundations with high practical applications, contributing to the development of the tourism industry.

- Culture is a unique resource of tourism (the source of raw materials to form tourism activities). When we say culture is the raw material to form tourism activities, we mean the attraction/beneficiary of the tourist. Cultural materials have two basic types: Physical culture is human creations that exist, exist in a space that can be perceived by sight, touch, such as historical and cultural relic's culture, handicrafts, tools in seed production, production, ethnic dishes, etc. An intangible culture such as festivals, art forms, behavior, communication ... According to the conception of In the tourism industry, cultural elements are classified into human resources (as opposed to natural resources such as seas, rivers, lakes, mountains, caves, etc.), namely: Historical - cultural relics; souvenir goods of national characteristics; cuisine; festival; entertaining games; customs, practices, behavior, communication; religious beliefs; literature - art.

Therefore, culture is the condition and environment for tourism to arise and develop. Along with natural resources, cultural resources are one of the typical conditions for tourism development of a country, region, and locality. The value of cultural heritage: historic sites, architectural works, art forms, customs, festivals, traditional professions, etc. together with economic, political, and communal achievements associations, cultural and art establishments, museums, etc. are objects for tourists to explore, enjoy, for tourism to exploit and use. The exploitation and profit from natural resources and the construction of tourist sites reflect the intelligence and creativity of mankind. It is these resources that not only create the environment and conditions for tourism to arise and develop, but also determine the scale, type, quality and efficiency of tourism activities of a country, a region, a locality.

The relationship between tourism and culture is also manifested through behavior, ethics in service, or in tourism business transactions. The essence of the relationship between culture and business in 
general and tourism in particular (or the role of culture in economic development) has been affirmed. In other words, business behavior to be successful must be done culturally. Can be called collectively as business art or business culture.

In another aspect, this close relationship is shown: if tourism development needs to have a good tourism environment (including the natural and human environment - these two factors inseparable). The natural environment such as no dirt, clean water, no writing on rocks, etc. the humanistic environment is a relic that is preserved, residents, employees working in the tourist area must have culture and quality complete culture, policy, legal system, etc.

Knowledge, social information, behavior, psychological understanding of tourists, etc. are effective drivers to promote tourism development.

In contrast to culture, tourism also plays a very important role in this relationship. Tourism becomes a means to convey and show the cultural values of a locality and people for all domestic and international tourists to explore, admire, learn, and enjoy.

Thanks to tourism, cultural exchanges between communities and countries are strengthened and expanded.

Tourism is also a means to awaken and revive the national cultural values that are submerged or fading overtime before historical events. These can be ancient architectural works, a living custom, a folk tune, a national dish, etc. showing the artistic, cultural, and technical level of the past times. Thanks to tourism, these cultural assets are restored, exploited, and embellished, serving the need to validate the values of that heritage.

From an economic point of view, thanks to tourism, it creates an income source that allows localities to accumulate and develop socio-economic; including culture. As a result, cultural assets will be protected, repaired, and embellished at the same time with the construction of new cultural facilities and the enrichment of contemporary cultural values. Because culture and tourism have such an interactive / mutual relationship, culture and tourism cannot be separated and even more irreversible.

Thus it is possible to confirm an argument: tourism is an integrated cultural activity or the connotation of tourism is culture and that culture is expressed either explicitly or implicitly throughout all aspects tourism activities. The main activities of tourism include food, accommodation, excursions, shopping, entertainment (internal human needs, etc.), in all those activities apart from serving meeting the essential life needs of all members of society with cultural characteristics and aspirations - expressing their admiration and pursuit for cultures of other places. Visitors can leave the rooms with high amenities to live in stilt houses, simple leaf houses can abandon modern means of transport to go on a canoe, ride a cyclo on the old streets, you can give up familiar dishes to enjoy "difficult to play" dishes, ready to spend a large amount of money to buy specialties of other countries, etc. The objects that visitors can see, eat, touch, and grasp are specific types of material, but they all contain some kind of spiritual culture that visitors go to see, buy, etc. The most important thing they choose is not the material itself but satisfying the psychological need to find the new, the strange, and the beauty (Luong, 2002). Therefore, although tourism is an economic industry in which economic activities are included, in general tourism is a cultural activity - a socio-cultural activity of humanity.

\section{The Sustainable Tourism Development and Tourism Culture at Vietnam}

\subsection{The Sustainable Tourism Development}


In the current period, sustainable tourism development requires the development of high-quality tourism products, capable of attracting and meeting the increasing needs of tourists, but without hurting harming the natural environment and indigenous culture, and taking responsibility for conservation and development of natural resources and the environment. In this regard, in Agenda 21 on the tourism and travel industry towards the environmentally sustainable development of the World Tourism Organization and the World Council identified "Sustainable tourism products the products are built in accordance with the environment, communities and cultures, thereby bringing certain benefits rather than threats to tourism development" (Luong, 2002).

One of the most important focuses of sustainable tourism development today is working towards a balance between socio-economic goals and the conservation of natural resources, environment, and community culture in when it must enhance the satisfaction of the increasing and diversified needs of tourists. This balance can change over time as there are changes in social norms, the conditions that ensure the ecological environment, and the development of science and technology. However, an approach to ensuring sustainable tourism development must be based on a balance of environmental resources with a unified plan.

In Vietnam, the concept of sustainable tourism development is still relatively new. But through lessons learned and practices about sustainable tourism development in countries around the world, tourism development in our country is moving towards responsible for natural resources and the environment. Therefore, many new types of tourism have emerged in Vietnam: ecotourism, nature tourism, green tourism, etc.

Among the new types of tourism developed in Vietnam just above, ecotourism is considered as an important approach to sustainable tourism development. Therefore, in September 1999, the Vietnam National Administration of Tourism cooperated with the World Union for Conservation of Nature and the Asia-Pacific Economic and Social Commission to organize a workshop on developing tourism development strategies. Ecological calendar in Vietnam. At this workshop, the definition of ecotourism was given for the first time in Vietnam. Accordingly, "Ecotourism is a type of tourism based on nature and indigenous culture associated with environmental education, contributing to conservation and sustainable development efforts with the active participation of local community" (Luong, 2002). This result is considered a favorable prelude to the next steps in promoting the development of ecotourism in particular and sustainable tourism in general in Vietnam.

Although leading experts in tourism and other related fields in Vietnam have not really agreed on the concept of sustainable tourism development, so far the majority The comments all said: "Sustainable tourism development is the managed exploitation of natural and human values to satisfy the diverse needs of tourists; take care of the long-term economic benefits and ensure contributions to the conservation and embellishment of resources, to maintain cultural integrity, to environmental protection for developing tourism activities in the future, and contribute to improving the living standards of local communities" (Luong, 2002).

On the basis of consistent with the interpretation of the concept of "Sustainable tourism development" of the Vietnam Tourism Law (2005). At the same time, with thinking towards the goal-oriented approach of the term "sustainable development", the concept of "sustainable tourism development" is proposed by the author as follows: "Sustainable tourism development is the development of tourism activities with spending brings economic benefits, creates jobs for society and community; satisfy the diverse needs of all sectors participating in tourism ... on the basis of exploitation of natural resources; 
At the same time, to be conscious of investing in embellishing, conserving and maintaining the integrity of natural resources, ensuring a clean environment; must attach responsibility and interests of the community in the exploitation, use, and protection of natural resources and the environment.

\subsection{Tourism Culture}

"Tourism culture is not a simple addition between culture and tourism, but a combination of tourism and culture, a spiritual and material result due to the mutual interaction between three types: cultural and emotional needs of tourist subjects (tourists), cultural content and values of tourists (tourism resources can satisfy spiritual and material enjoyment of people), the cultural consciousness and qualities of travel brokers (guides, narrators, product designers, service staff, etc.) are produced: (Luong, 2002). Anyone of these three factors can not alone create a tourism culture. If you are separated from tourists, you will lose the target audience to enjoy and not fulfill cultural aspirations. Without a travel agent, the tourist subject and the tourist object cannot meet each other, tourism cannot be performed, without tourism, of course, tourism culture cannot arise. If there are no tourists, the tourism industry only has a reputation, it will not produce a new tourism culture, and even the inherent cultural and tourist components cannot be shown.

Thus, tourism culture means the cultural content expressed by tourism - is the culture accumulated and created by tourists and tourists in tourism activities. Tourism culture is born and develops with tourism activities.

The culture of the tourist subject is reflected in the process of enjoying tourism. Above all, it is expressed through a sense of the need for tourism because it clearly shows a certain cultural level and the social needs of many people. The concept of value, the form of thinking, aesthetics, personality, emotions, etc. will be revealed in tourism activities and it reflects national psychology. In addition, it is also expressed through travel behavior towards beauty, to cherish and cherish beauty. Unfortunately, many beaches, many landscapes are getting dirtier and dirtier because of the waste, not to mention the guestbook lines with all types on the cliffs, tree trunks, even engraved on the ancient beer, etc.

Tourists are the material base of tourism culture, these facilities provide both objects for tourists to visit and enjoy excursions, and only under the care of tourism can works.

The culture of the tourist is expressed through the values that tourism resources can provide to visitors, the values of sanitary aesthetics, the environment of the ability to improve physical and knowledge for tourists visitors, not to mention the very broad concept of values itself. For example, a tourism resource is a historical and cultural relic, the aesthetic value here is to respect the authenticity, the restoration, and embellishment of the relic deformation, losing the original beauty its head, in violation of the originality - historical authenticity of the monument, which can be considered a non-cultural act. This not only does not have the effect of attracting tourists but also to a certain extent harms the image of the tourist destination, the general cultural image of the country.

The culture in the tourist is also considered as a standard to define the quality of tourism products:

The tourism industry includes both tourism services, tourist site management, direct customer contact, also includes the construction of tourist sites, sites, program design, and arrangement of service facilities. ... The most basic task is to bridge between the subject and the tourist in search of beauty and providing beauty. The culture shown in this agency is the tourism industry when designing tourism routes, building tourist sites, tourist establishments, services, etc. must create a cultural character. Must 
have the effect of improving the taste of visitors' life, making visitors feel peaceful, relaxed, enriching knowledge about nature, people and culture, and feel the beauty of the world natural, humanistic philosophy and indigenous culture.

It is necessary to ensure the rationality and optimization of investment in tourism infrastructure and equipment, but in addition to international practice, it must also have its peculiarities. According to the tourist routes and destinations that have been detailed planning, step by step building the system of roads, means of transport, accommodation establishments: hotels, restaurants, shopping places; means of communication, etc. according to international standards, the more modern, the more convenient, the easier it will be to attract customers. However, in addition to international practices, tourism also has facilities, infrastructure, and equipment bearing the national cultural identity that attracts tourists. For example, in the scenic spots, the landscape must keep the bumpy road meandering through the slopes, riverside, up to caves, pagodas for tourism.

Cannot or absolutely not concreted, bricked, completely petrified the winding, winding roads that are the "soul" of the tourist destination. Losing that soul, the value of tourism will be reduced and tourism quality will also decline. Or in tourist spots, which are ancient villages and towns, when planning and construction must ensure that they do not damage the space, preserve old roads, old houses, old bridges, markets, places of living. This point can only confirm its own unique and distinctive values of residents' community. Even in hotel and restaurant equipment, in addition to the international part, there must be an increase in the rate of unique facilities and infrastructure equipment such as architectural design, interior decoration, decorative patterns decorations, items, etc. made from traditional crafts such as embroidery, silk, pottery, stone, sedge, etc.

\section{Ethnicity in architectural decoration:}

The culture is also manifested by the behavioral attitude, wide understanding, accurate scientific habits of the travel agent, especially the product designer and especially the tour guide - the person who goes directly with the tourist/tourist subject during the tour, who is charged with finding beauty and providing it to the tourist.

In addition, tourism development must have a good tourism environment (including natural ecological environment and human social environment). The humane social environment includes the level of social development, intellectual level, and the standard of living, a sense of respect for the law, including the entire system of institutions, laws, mechanisms, and policies. A favorable human social environment, especially a clear legal environment consistent with international practices, will have a positive effect on encouraging tourism development.

Tourism is a cultural activity, but in the end, it is still a business activity so its products must also be cultural:

In order to have a system of cultural tourism goods and products, it must be expressed in all details from the tourist route, tourist destination, tourist vehicle, and services, etc. in general, it must be built products meet two requirements: the distinctive and symbolic of the national culture.

Not any tourism product exploited from national culture is also unique, although the culture itself is specific to each country. Exploiting the elements of the national culture's identity and characteristics to form tourism products is to create unique and distinctive cultural products. 
Tourism to ethnic minority areas is of interest to the world because there you will be able to observe and learn about unique, unique and unique customs, lifestyles and cultural values. Many countries around the world have ethnic minorities. However, in Vietnam, there are comparative advantages in developing tourism to ethnic minority areas. That advantage is reflected in the preservation of primitive features of ethnic cultures, in their lifestyles, customs, farming habits or in architecture, costumes, in cultural, artistic and vocational activities traditional crafts. Especially, those cultural features are mixed with the beautiful natural ecological space, which attracts tourists. In addition, the attraction of cultures of ethnic minorities in Vietnam is the diversity in the unity of national cultures. Thus, investment in developing tourism to ethnic minority areas is to create a unique and unique type of cultural tourism in Vietnam.

Every country has a system of urban centers, but when visitors come to Hanoi capital, they will surely find it interesting, even unexpected, when coming here, coming to the city, meeting the traditional folk "villages". In particular, the jobs that are both rare and ancient with "technology" and "technological process" and its special products - are the valuable strength and attractions for tourism traveler. In addition, most of the special craft villages like this, in its overall, harmonious form, are all "cultural and poetic villages" with landscapes - customs (the leading is festivals) rich and attractive. Tourism certainly finds the ideal point here: a unique cultural tourism product full of attractions.

Likewise, ecotourism is being interested and directed by the whole world. In many countries, the resources to create this product are very plentiful, but only in Vietnam can the rural agricultural ecosystem in the monsoon tropics is extremely diverse, unique with fields and fragments. gardens, fish ponds, plants, animals ... associated with it are methods of using and protecting land, water sources, plants and animals, farming methods, etc. living scenes of people means raw production and it is a unique source of materials for Vietnamese tourism to create a unique tourism product.

The cultural identity of a country, a locality is a foundation for creating iconic products that appeal to tourists. Obviously, it is impossible to create the iconic tourism products of Vietnam by copying or borrowing from the tourism products of Bangkok, Beijing, or Malaysia but from the typical cultural values of Vietnam. Because culture is the foundation of society, expressing the height and depth of national development, creating tourism products that represent the national culture plays an important role in identify the image of that country and of the tourism industry.

Tourism culture is a wide category, expressing the cultural values of the entire tourism activity. All activities of each department, tourism products in the process of creation are aimed at forming the unique characteristics of the national culture, which will help form a tourism culture country-specific calendars.

Thus, the whole harmonious relationship between tourists, tourists, travel brokers, tourism products, and institutions has created a part of tourism culture. Today, tourism culture has become a new element in the cultural category of each country.

\section{Conclusion}

The tourism development process that ensures the above problems are addressed will be assessed as sustainable. However, that development is only relative because in society there is always change and development, the sustainability of this factor may be the cause that affects the sustainability of other factors. 
It can be said that tourism has promoted the protection of the country's cultural treasures. It is the needs of visitors to visit, learn, and experience that motivates the government and people to appreciate, be proud, take care of, preserve, restore, and clarify, and promote the values precious capital of cultural heritage. Heritage tourism creates both income and employment, both creating motivation and creating resources to preserve and promote heritage values; at the same time, actively support to improve the quality of life, enhance understanding, respect for diversity and cross cultures, as a basis for forming a suitable code of conduct between people and tourists and heritage. The benefits of heritage tourism are not small and are shared with businesses and people. Some of the revenue from heritage tourism is returned to be reinvested in heritage conservation, embellishment, honor, restoration, and management. In that sense, heritage tourism makes a great contribution to the conservation and sustainable promotion of cultural heritage.

However, in the current strong growth tourism trend, especially mass tourism has had and is having negative impacts on cultural heritage. Due to the sensitive and vulnerable nature of the heritage, the mass tourism movement lacks control in many places, especially the famous heritages in our country that are spreading a lot of impacts aspects such as overexploitation of commercialization, overloading of guests, abuse of heritage, improper restoration, heritage renewal, etc. make the legacy quickly degrade, distort, and fade its value, etc. The consequences of uncontrolled and unsustainable heritage tourism development are threatening the integrity of the heritage. Over the past time, in some famous heritage, there have been development investment activities, including serious harms to the heritage that the next phase will pay very expensive prices for the restoration of diurnal value property has been compromised. No society or economy can achieve absolute sustainability. All human activities, all measures are only aimed at ensuring the long-term exploitation of natural resources.

\section{References}

1. B. Bramwell \& B. Lane (Eds.), (1993). Tourism Collaboration and Partnerships. Politics, Practices and Sustainability. Canada: Channel View.

2. Brundtland Commission, (1987). Our Common Future. Publisher: Oxford University Press.

3. Dwyer, L., \& Edwards, D. (2010). Sustainable Tourism Planning. In Understanding the Sustainable Developmentof Tourism; Liburd, J. J., Edwards, D., Eds.; Goodfellow Publishers: Woodeaton, UK; pp. 19-44, ISBN 978-1-906884-13-0

4. Inskeep, E. (1995). National and Regional Tourism Planning, Metholodogies and Case Studies. Routledge, London.

5. ICOMOS. (2004). The World Heritage List: Filling the Gaps - an Action Plan for the Future.

6. Luong, P. T. et al. (2002). Scientific Basis and Solutions for Sustainable Tourism Development in Vietnam. State-level research topic.

7. Hens L. (1998). Tourism and Environment. M.Sc. Course, Free University of Brussel, Belgium.

8. Machado A. (2003). Tourism and Sustainable Development, Capacity Building for Tourism Development in Vietnam. VNAT and FUDESO, VietNam.

9. Meyer, B., \& Milewski, D. (2009). Strategie Rozwoju Turystyki Regionie. Wydawnictwo Naukowe PWN.

10. National Assembly of the Socialist Republic of Vietnam. (2001). Heritage Law.

11. Peeters, P., \& Dubois, G. (2010). Tourism travel under climate change mitigation constraints. Journal of Transport Geography. 18 (3); pp. 447-457. Doi:10.1016/j.jtrangeo.2009.09.003 
12. Philip L. Pearce, \& Gianna Moscardo, (1985). Tourist Theme Parks: Research Practices and Possibilities. Australian Psychologist 20(3), pp. 303-312. https://doi.org/10.1080/00050068508256175.

13. Ronald Carter, (1993). Ecotourism in the Third World: Problems for Sustainable Tourism Development. Tourism Management $\quad$ 14(2), $\quad$ pp. https://doi.org/10.1016/02615177(93)90040-R

14. Shaker, Richard Ross, (2015). The spatial distribution of development in Europe and its underlying sustainability correlations. Applied Geography 63; pp. 304-314. doi:10.1016/j.apgeog.2015.07.009

15. Sultan Sevinc Kurt Konakoglu \& Banu Çiçek. (2018). Tourism and Tourist Types in Urban Tourism. Publisher: Cambridge Scholars Publishing.

16. UNESCO. (2004). What is Intangible Cultural Heritage? Retrieved from: https://ich.unesco.org/en/what-is-intangible-heritage-00003 